\title{
eCOti
DiAno
}

Revista Mídia e Cotidiano

ISSN: 2178-602X

Artigo Seção Livre

Volume 15, Número 2, maio/ago. de 2021

Submetido em: 23/11/2020

Aprovado em: 28/04/2021

\section{Estereótipos associados à religiosidade afro-brasileira nas narrativas jornalísticas cariocas na década de 1920}

Afro-Brazilian religiosity stereotypes in 1920s Rio's journalistic narratives

\section{Estereotipos asociados con la religiosidad afrobrasileña en las narrativas periodísticas de Río en la década de 1920}

\author{
Ronivaldo Moreira de SOUZA ${ }^{1}$ \\ Maurício Ribeiro da SILVA ${ }^{2}$
}

\begin{abstract}
Resumo
Ao longo do processo de formação sócio-histórica do Brasil, os colonizadores construíram narrativas com imagens estereotipadas dos africanos escravizados e de sua religiosidade a partir de uma visão europeia e cristã. Mesmo depois da abolição da escravidão esses estereótipos permaneceram associados à religiosidade afro-brasileira e foram apropriadas pelas narrativas jornalísticas, contribuindo para reverberar essa estereotipia até o tempo presente. O objetivo deste artigo é analisar os estereótipos associados à religiosidade afro-brasileira na década de 1920 nas narrativas jornalísticas da imprensa carioca. Tendo como base os pressupostos teórico-metodológicos da Análise do Discurso de Escola Francesa, compomos o corpus da pesquisa com 24 textos, dos quais, dois são tomados para análise no artigo e considerados como representativos da seleção. Constatamos que nas narrativas analisadas a religiosidade afro-brasileira é demonizada, configurando a estereotipia.
\end{abstract}

Palavras-chave: Religiosidade Afro-Brasileira. Estereótipos. Análise do Discurso. Jornalismo.

\begin{abstract}
Throughout Brazilian social and historical formation, the colonizers' narratives used a lot of stereotyped images from a European and Christian point of view of the African slaves and their religiosity. Even after the abolition of slavery, these stereotypes remained associated with Afro-Brazilian religiosity, being appropriated by journalistic narratives that contributing to reverberate these stereotypes to the present day. This article aims to analyze the stereotypes used by the Rio de Janeiro press concerning Afro-Brazilian

\footnotetext{
1 Pós-doutorando pelo Programa de Pós-graduação Stricto Sensu em Comunicação da Universidade Paulista (UNIP-SP). E-mail: ronivaldomds@gmail.com. ORCID: 0000-0002-2124-9986.

2 Professor Titular e Coordenador do Programa de Pós-graduação Stricto Sensu em Comunicação da Universidade Paulista (UNIP-SP). E-mail: silva.mrib@gmail.com. ORCID: 0000-0002-7152-2581.
} 
religiosity in the 1920s. Based on the theoretical and methodological assumptions of the French School's Discourse Analysis, we took 2 representative texts from 24 that make up the research corpus. The conclusion is that in the narratives analyzed, Afro-Brazilian religiosity is demonized, configuring stereotypes.

Keywords: Afro-Brazilian religiosity. Stereotypes. Discourse Analysis. Journalism.

\section{Resumen}

A lo largo del proceso de formación socio-histórica en Brasil, los colonizadores construyeron narrativas con imágenes estereotipadas de africanos esclavizados y su religiosidad desde una perspectiva europea y cristiana. Incluso después de la abolición de la esclavitud, estos estereotipos permanecieron asociados a la religiosidad afrobrasileña y fueron apropiados por las narrativas periodísticas, contribuyendo a reverberar este estereotipo hasta la actualidad. Partiendo de los supuestos teóricos y metodológicos del análisis del discurso de la escuela francesa, formamos el corpus de la investigación con 24 textos, de los cuales 2, considerados representativos de la selección, son enviados para su análisis en el artículo. Se concluye que en las narrativas analizadas se demoniza la religiosidad afrobrasileña, configurando un proceso de estereotipo.

Palabras clave: Religiosidad Afrobrasileña. Estereotipos. Análisis del Discurso. Periodismo.

\section{Introdução}

- Como é que pode... isso é uma histeria coletiva, um devaneio, gente possuída, doideira...

- Amigos...por favor... só Jesus é o caminho, parem com isto.... acreditar em imagem de barro, poluir os mares, sujar as praia (Sic), macumbaria, bebedeira... ...que feio...isto é atraso de vida falta de cultura, pura burrice (PORTAL G1, 2020).

Esses são dois dos muitos comentários de leitores da matéria com o título "Baianos e turistas celebram Iemanjá em Salvador; multidão se forma no Rio Vermelho", publicada no Portal G1 no dia 02 de fevereiro de 2020. Apesar do texto jornalístico observar os efeitos de objetividade característicos dessa tipologia discursiva, são vários os comentários dos leitores que rotulam tanto a religiosidade afro-brasileira quanto os seus adeptos de diabólicos, loucos e sem cultura.

Para compreender essas manifestações de intolerância e preconceito que agora emergem nos espaços públicos, nas mídias capazes de rede, precisamos assumir que o discurso é uma construção sócio-histórica, que é ao mesmo tempo constituído e constitutivo das práticas sociais e que essa visão estereotipada da religiosidade afro- 


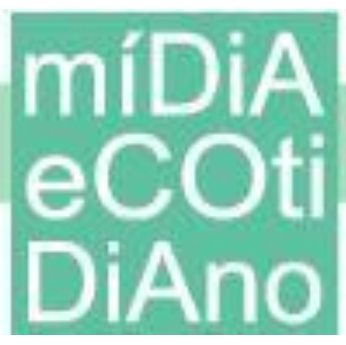

brasileira, mais do que um dado do tempo presente, é uma construção que remonta ao período da colonização, visto que desde os primeiros relatos europeus emergem imagens estereotipadas da religiosidade indígena as quais foram posteriormente atribuídas, também, à afro-brasileira, ambas vistas a partir de uma perspectiva europeia e cristã. Tais narrativas estereotipadas, que a princípio cumpriam função de registro histórico, foram apropriadas no discurso hegemônico, sendo consolidadas no imaginário social brasileiro e, portanto, também popularizadas pela mídia.

Com esta compreensão em mente, nos propomos a identificar este processo em sua gênese, presente no jornalismo do início do século XX. Como é sabido, os jornais passam a circular no Brasil, de forma mais consistente, somente a partir da segunda metade do século XIX, tornando-se - mais do que um espaço dedicado à notícia do cotidiano - o principal veículo para o consumo de obras literárias, de circulação de ideias, construção de narrativas hegemônicas e contra-hegemônicas etc.

Sendo o Brasil da época um país profundamente iletrado, os jornais chegam ao século XX ou como expressão de uma sociedade que se urbaniza, verbalizando tanto a visão das elites quanto de grupos sociais - mais notadamente o operariado - que buscam contrapor e constituir narrativas que visavam a conquista de espaço na sociedade (JARDIM, 1996).

São exemplos deste primeiro grupo jornais como os cariocas Jornal do Brasil, Gazeta de Notícias e A Noite, o gaúcho Correio do Povo e o paulista O Estado de S. Paulo. Neles e outros jornais, geridos em concordância com a visão empresarial, manifesta-se dentre outros assuntos a perspectiva das elites acerca da massa de trabalhadores, tanto os europeus recém-imigrados quanto os escravizados e seus descendentes, que libertos poucos anos antes, passam a formar importante contingente urbano.

$\mathrm{Na}$ esteira do positivismo e do cientificismo do século XIX, os jornais passam a constituir importante espaço no debate das manifestações espíritas (DEL PRIORE, 2014), constituindo inquéritos ou dossiês com sequências de reportagens sobre o tema. Tais colunas frequentemente eram apresentadas em locais de destaque logo nas primeiras páginas, denotando tanto a importância quanto a receptividade do tema.

O mais famoso e conhecido destes inquéritos, produzido por João do Rio em 1904, a coluna As Religiões no Rio, chegou até nós como um dos mais importantes 


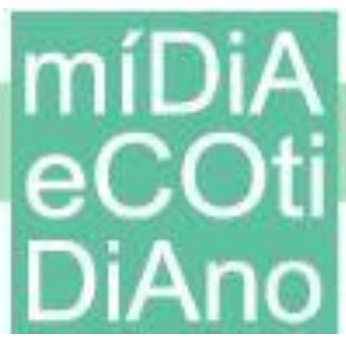

documentos etnográficos do Rio de Janeiro no começo do século. Assim como os folhetins literários, tamanha era a procura que tais dossiês, após a conclusão da publicação nos jornais, eram transformados em livros, muitos deles lançados pela Editora e Livraria Garnier, conhecida por ser a responsável pela publicação de Memórias Póstumas de Braz Cubas e outras obras de Machado de Assis, o que denota uma estratégia de mercado e, consequentemente, a existência de um consistente consumo deste tipo de produção (SILVA, 2019).

Neste ambiente composto por um misto de curiosidade e interesse "científico", não era rara a ocorrência de temas ligados à religiosidade dita "africana" que, até então, quando surgia, estava associada a espaços dedicados a notícias policiais. De todo modo, a despeito da mudança no interesse, permanecia a crença na superioridade europeia sustentada no pseudocientificismo das teorias de Cesare Lombroso tanto sob o ponto de vista biológico quanto social, considerando, portanto, tais práticas evidências de atraso mental e civilizatório e, assim, frequentemente associadas ao imaginário europeu medieval, ligado à ideia de feitiçaria ou malefício.

Assim, dada a hipótese de permanência do imaginário social nos comentários acerca de produções jornalísticas contemporâneas, propusemo-nos a analisar quais estereótipos estão associados à religiosidade afro-brasileira na década de 1920 na imprensa carioca, dando especial atenção ao seu funcionamento discursivo, buscando também compreender como eles interferem na percepção que os enunciadores têm do fenômeno religioso afro-brasileiro que emergia na periferia do Rio de Janeiro na citada década.

A delimitação geográfica no Rio de Janeiro é decorrente de dois fatores: tanto pelo fato de ser, na época, a capital federal (ao mesmo tempo representativa e influenciadora da sociedade brasileira) e pelo fato de ser, no início do século XX, um local de grande efervescência religiosa, onde, além do tradicional catolicismo, observase importante manifestação do Espiritismo, de cultos africanos associados ao Candomblé e denominados genericamente de Macumbas, além de outros grupos como os maronitas, os fisiólatras, evangélicos ou judeus (RIO, 2015). Por fim, é o epicentro da emergência da Umbanda, uma religião espírita que apresenta traços sincretizados do Catolicismo, do Espiritismo, de religiões africanas - mais notadamente o Candomblé - e indígenas - como a Jurema Sagrada. Esta condição de interface da Umbanda possibilita observar o 


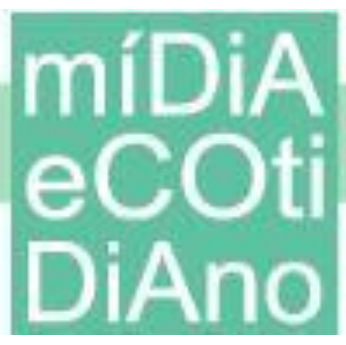

acionamento de discursos antagônicos - ora associados ao europeu, ora ao africano -, tornando mais evidente o interdiscurso e a compreensão das suas condições de produção.

Mesmo havendo discrepância das pesquisas que de algum modo abordam o surgimento da Umbanda, há convergência na compreensão de que é na década de 1920 quando o debate público se estabelece de modo consistente e acirrado (SILVA, 2019). Apesar de hoje ser associada ao Candomblé e pertencer ao grupo de religiões de matriz africana, a Umbanda era naquele período retratada como uma prática associada ao Espiritismo, compartilhando com este grupo as concepções dogmáticas e aspectos doutrinários, apesar de algumas divergências litúrgicas.

Nossas pesquisas nos periódicos cariocas da década de 1920, indicam o intenso debate nos jornais de grande circulação da época acerca do "lugar" da Umbanda entre os polos antagônicos estabelecidos a partir do cristianismo, visto como civilizado e correto pela sociedade de então, e o africano, tido como associado à ideia de feitiçaria e malefício. Os jornais, então, mobilizam narrativas antagônicas que por um lado acusam e por outro refutam acionamentos do imaginário social com o qual eram descritos os africanos e seus descendentes e que, na contemporaneidade, ainda observamos ativos.

Para grifar estes traços em uma abordagem qualitativa e contrastá-los com as manifestações contemporâneas, selecionamos dois textos representativos daquela situação, publicados ao longo da década de 1920 e disponibilizados no acervo da Hemeroteca Digital da Biblioteca Nacional (HD-BN) por meio da palavra-chave $<$ Umbanda>, submetendo-os ao método da Análise do Discurso de Escola Francesa.

Inicialmente apresentaremos os pressupostos teórico-metodológicos da Análise do Discurso (AD) de Escola Francesa que vão orientar nossa abordagem do fenômeno. Em seguida, faremos a apresentação dos resultados intercalando o referencial teórico com a aplicação da metodologia tornando, desse modo, o texto mais didático.

\section{Metodologia}

O quadro epistemológico geral da AD engloba três áreas do conhecimento: “1) o materialismo histórico, como teoria das formações sociais e suas transformações; 2) a linguística, como teoria dos mecanismos sintáticos e dos processos de enunciação; 3) a teoria do discurso, como a teoria da determinação histórica dos processos semânticos" 


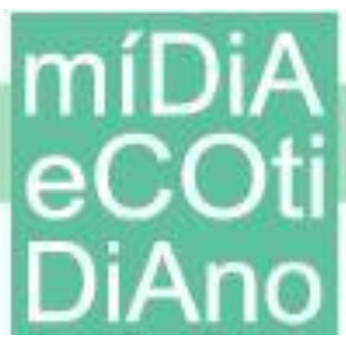

(BRANDÃO, 2004, p. 38). O sentido é o ponto nodal entre a linguística, a filosofia e as ciências sociais. Sendo assim, a finalidade "não é interpretar, mas compreender como um texto funciona, ou seja, como um texto produz sentidos" (ORLANDI, 2011, p. 19).

Essa metodologia rompeu com a noção realista de que a linguagem era apenas uma ferramenta - um instrumento acabado do qual os emissores lançam mão -, ou um meio para um fim: refletir ou descrever o mundo. Ao contrário, a $\mathrm{AD}$ adotou uma “convicção da importância central do discurso na construção da vida social [...] e rejeitou a noção do sujeito unificado coerente, que foi ao longo do tempo o coração da filosofia ocidental" (GILL, 2002, p. 245-246). Assim, o processo de produção de um discurso "é o conjunto de mecanismos formais que produzem um discurso de tipo dado em 'circunstâncias' dadas” (PÊCHEUX, 1997, p. 74).

Maingueneau (1997) em releitura da obra de Pêcheux, estabeleceu os limites e objetivos metodológicos da Análise do Discurso. O autor teceu duras críticas contra a tendência de transformá-la em mais um método hermenêutico, cujo objetivo é descobrir o sentido de um determinado texto. O papel da AD, segundo o autor, é descrever os processos que tornam possíveis os sentidos de um determinado discurso.

Maingueneau (1997, p. 13-14) sistematiza essa composição metodológica ao afirmar que a $\mathrm{AD}$ deve basear-se em três dimensões: o quadro das instituições que restringem fortemente a enunciação; os embates históricos e sociais que se cristalizam no discurso; o espaço próprio que o discurso configura para si no interior de um interdiscurso.

Por sua vez, a delimitação do corpus que comporá a sua análise, não deve circunscrever o olhar do analista, partindo do princípio de que aquele discurso é produção de um determinado sujeito. O objeto da $\mathrm{AD}$ não é o texto tomado em sua singularidade. Ao contrário, deve "considerar sua enunciação como o correlato de uma certa posição sócio-histórica na qual os enunciadores se revelam substituíveis" (MAINGUENEAU, 1997, p. 14).

Assim, a AD compreende que todo discurso é circunstancial. Em outros termos, parte do pressuposto de que o discurso cristaliza práticas que são culturais e sociais e não as intenções confinadas em um indivíduo singular (PISA; SOUZA; VISIBELI, 2018, p. 18). 


\section{míiA
eCOti
DiAno}

\section{Seleção do corpus}

Para garantir a cientificidade do procedimento, alguns critérios precisam ser observados na construção de um corpus. O primeiro visa resguardar uma construção equilibrada. Barthes afirma que o corpus é "uma definição finita de materiais, determinada de antemão pelo analista, conforme certa arbitrariedade (inevitável) em torno da qual ele vai trabalhar" (BARTHES, 2006, p. 104).

Sobre esse primeiro aspecto da seleção, buscamos o acervo da HD-BN, um dos mais amplos e acessíveis do país. A partir da palavra-chave $\langle$ Umbanda $\rangle$, restringimos a seleção ao Estado do Rio de Janeiro no período entre 1920 a 1929. Dentre todos os periódicos disponíveis, a pesquisa apresentou 45 ocorrências sendo 21 excluídas por conter termos correlatos ${ }^{3}$. Dentre as 24 ocorrências validadas, selecionamos 2 pelo critério de aleatoriedade (GIL, 2002, p. 47) compreendendo que são representativas do total selecionado para a composição do corpus $^{4}$.

Barthes (2006) aponta que para um delineamento consistente devemos observar critérios de pertinência, homogeneidade e sincronicidade. O critério de pertinência é também um princípio limitativo, já que ao construir o corpus o pesquisador descreve os fatos reunidos a partir de um ponto de vista e se propõe a reter da massa heterogênea aqueles que efetivamente interessam, com apenas um foco temático. Também é necessário garantir que a substância material dos dados seja tão homogênea quanto possível: textos, imagens e sons, quando possível, devem ser categorizados e analisados distintamente. Por fim, ressalta-se que um corpus é uma intersecção na história. Portanto, os materiais selecionados devem ser escolhidos dentro de um ciclo natural. É este ciclo que possibilita ao pesquisador um recorte sincrônico e preciso (BARTHES, 2006, p. $103 ; 105)$.

Diante deste quadro, nesta pesquisa delimitamos o recorte tendo como base os estereótipos presentes na imprensa carioca na década de 1920, associados à religiosidade

\footnotetext{
${ }^{3} \mathrm{O}$ algoritmo trouxe, além do termo <Umbanda>, leituras similares como "uma banda", "Sarabanda", "Retumbância", entre outros. Não sendo ajustados aos propósitos da análise, esses resultados foram excluídos da amostra.

${ }^{4}$ Reconhecendo as limitações na dimensão de um artigo, selecionamos 2 textos para proceder a análise dentre os que formam o corpus. Sendo o foco da AD o processo de produção de sentidos, entendemos que ambos possibilitam adequadamente a verificação do contexto sócio-histórico-cultural, sendo os resultados apontados nessa pesquisa, portanto, representativos do corpus selecionado.
} 


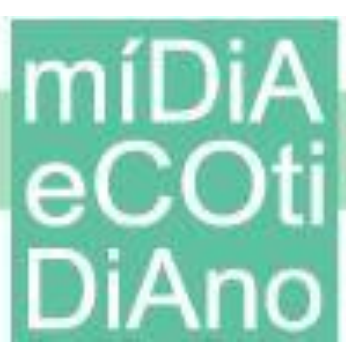

afro-brasileira tanto com materiais em linguagem textual (escrita) quanto imagética (fotos e ilustrações). Essa delimitação se justifica por ser esse o período em que a religiosidade afro-brasileira que vinha crescendo nas regiões periféricas do Rio de Janeiro, começa a assumir contornos mais evidentes na vida social ao ponto de começar a surgir com mais frequência nas narrativas jornalísticas.

Os dados disponíveis na HD-BN associados ao termo <Umbanda> nos periódicos do Rio de Janeiro no início do século XX apontam o súbito aumento do número de resultados na década de 1920 em comparação com a década anterior: entre 1910 e 1919, identificamos 11 resultados, passando para o patamar de 370 no período seguinte, entre 1920 e 1930.

Nesta década, além do incremento quantitativo, destaca-se o surgimento de narrativas nas quais os repórteres vão à periferia testemunhar os "mystérios" que circundam a religião para, nas páginas dos jornais, narrar a própria percepção daquilo que viram e testemunharam. O sucesso dessas narrativas e a aceitação entre os leitores é evidenciada não apenas pela proliferação nos periódicos, mas pela extensão que ocupam: muitos são textos de página inteira, contando com ilustrações e fotos, um recurso bastante sofisticado para a época.

Diante do quadro, focamos nesse tipo de narrativa e dentre elas selecionamos duas que evidenciam de modo mais consistente a percepção social sobre a religiosidade afro-brasileira nesse período histórico e ao mesmo tempo marcam a presença da estereotipia como parte do processo de produção de sentidos nos discursos.

O primeiro texto selecionado foi assinado por Benjamim Costallat e tem como título "Na noite do subúrbio". Foi publicado no dia 24 de maio de 1924 no Jornal do Brasil ocupando mais de uma página do periódico. O segundo, foi publicado no Jornal Crítica no dia 07 de novembro de 1929 e ocupa praticamente toda a primeira página da edição do periódico. O texto traz como título principal: "Para as suas 'mandingas e trabalhos' a bruxa de Itinga emprega bichos e pós venenosos". 


\section{míDiA \\ ecc DiAno}

\section{Resultados}

\section{O acontecimento e a construção do acontecimento no discurso midiático}

É preciso, em primeiro lugar, considerar o suporte no qual esse discurso é veiculado. No início da década de 1920 a imprensa escrita dominava o fazer jornalístico visto que o rádio e a televisão somente ganhariam espaço e se tornariam referência posteriormente.

Este dado nos ajuda a compreender para qual enunciatário os periódicos cariocas se dirigiam, já que a imprensa escrita exige a competência de domínio do código linguístico para leitura. Segundo dados do $\operatorname{IBGE}^{5}$ em 1920, contando-se a população de 5 anos acima, o analfabetismo atingia o percentual de $71,2 \%$ dos brasileiros, sendo dominante entre negros e pobres.

Para a burguesia carioca alfabetizada, na década de 1920 as histórias, os contos, as crônicas e demais gêneros do discurso jornalístico, para além de informar sobre o comércio e o mundo civilizado, eram também narrativas dos acontecimentos extravagantes de um "mundo não civilizado" que existia na periferia e que não só contrastava como rompia com a ordem do mundo.

Em segundo lugar, precisamos considerar que na década de 1920 os periódicos brasileiros aproximavam-se do modelo francês de jornalismo, que adotava técnicas de escrita muito próximas das literárias. A crônica, o artigo polêmico e o gênero opinativo livre dominavam a estilística jornalística. Somente após à década de quarenta a imprensa começa a adotar as técnicas americanas, afastando-se gradativamente do estilo literário e adotando linguagem impessoal, esvaziando o texto do caráter emotivo do participante por meio de comunicação direta, sem uso de metáforas e adjetivos (RIBEIRO, 2003, p. 148149).

Dito isto, passemos a considerar a natureza tipológica do corpus analisado nesta pesquisa, retomando a descrição minuciosa que Charaudeau (2010) faz do processo de transformação do acontecimento em notícia pela instância midiática. Para ele, o acontecimento midiático nunca se apresenta à instância de recepção em estado bruto, pois,

\footnotetext{
${ }^{5}$ BRASIL. Ministério da Agricultura, Indústria e Comércio. Diretoria Geral de Estatística. Recenseamento Geral do Brasil: 1920. Rio de Janeiro, 1920. v. 4, pt.4: população. Disponível em: https://biblioteca.ibge.gov.br/visualizacao/livros/liv6478.pdf. Acesso em: 02 abr. 2020.
} 


\section{míDiA

para adquirir significado, depende do olhar de um sujeito que o integra a um sistema de pensamento (CHARAUDEAU, 2010, p. 96, 99).

Esse processo de construção do acontecimento que Charaudeau (2010) denominou de evenemencial constitui-se de três etapas: 1) modificação - uma mudança no estado do mundo provoca transformações na ordem das coisas com implicações para os seres humanos e não humanos; 2) percepção - a competência de um determinado sujeito em ver descontinuidade e ruptura no contínuo estado do mundo e 3) significação - essa modificação do mundo deve interessar ao sujeito como ser social, produzindo nele um efeito de pregnância (CHARAUDEAU, 2010, p. 100).

Perec (2008) observa que nas manchetes quem fala é sempre o incomum e o extraordinário. Trens só se destacam quando descarrilham, os aviões quando sequestrados e automóveis quando colidem. Em todos os casos, quanto maior o número de mortes, maior o destaque. Nesta perspectiva, o acontecimento midiático depende do escândalo, da fissura, do perigo, como se a vida não existisse para além do espetacular, como se o eloquente e significativo sempre fosse o anormal. O ordinário e o infraordinário que são verdadeiramente constituem o cotidiano desaparecem dos noticiários. Assim, o que o jornalismo qualifica como narrativas do cotidiano são, na verdade, narrativas daquilo que não é o cotidiano, que foge à normalidade, à continuidade e à naturalidade (PEREC, 2008, p. 21-22).

Por outro lado, o aspecto sincrônico do discurso jornalístico, à medida em que ancora a construção desse acontecimento em um tempo e um espaço verificável da vida social comum, devolve discursivamente a esse mesmo acontecimento sua característica cotidiana.

Observemos o primeiro parágrafo do texto sobre "a bruxa de Itinga", publicado pelo jornal Crítica em novembro de 1929:

toda a atenção temerosa, não só dos habitantes do vilarejo, que escolheu para cenário de suas demoníacas façanhas, mas de todo o Rio, que se abebera, sôfrego, dos acontecimentos fantomaticos com que ela nos tem sacudido os nervos, em sobressaltos, na reportagem sensacional que divulgamos dia a dia mais intensamente interessante, à mutação de seus aspectos e à sucessão de seus episódios (CRÍTICA, 1929). 
No texto, verificamos o esforço de extrair o acontecimento da naturalidade e continuidade da vida cotidiana por meio de expressões como "pitonisa de Itinga", "demoníacas façanhas", "acontecimento fantomatico". A saliência e a modificação é, nesse caso, também uma construção discursiva.

Em seguida, o enunciador ressalta a maneira como esse evento incomum que descreve afeta a vida cotidiana do vilarejo de Itinga e do Rio, com afirmações de que esse evento narrado cria uma "atenção temerosa" que "sacode os nervos em sobressalto e dessedenta a curiosidade do leitor".

Por fim, o texto devolve esse acontecimento ressignificado ao espaço da vida cotidiana dando-lhe um lugar verificável na vida social (Itinga) e um tempo contínuo de sua ocorrência (dia a dia). O efeito de cotidianidade da narrativa diz muito mais sobre a rotina do periódico e a habilidade jornalístico/literária do autor em narrar "dia a dia mais intensamente interessante" o acontecimento, do que o cotidiano de onde o acontecimento emerge.

Nessa perspectiva, podemos afirmar que o acontecimento midiático, enquanto notícia, só existe no/pelo discurso.

Por trás do discurso midiático, não há um espaço social mascarado, deformado ou parcelado por esse discurso. O espaço social é uma realidade empírica compósita, não homogênea, que depende, para sua significação, do olhar lançado sobre ele pelos diferentes atores sociais, através dos discursos que produzem para tentar torná-lo inteligível. Mortos são mortos, mas para que signifiquem "genocídio", "purificação étnica", "solução final", "vítimas do destino", é preciso que se insiram em discursos de inteligibilidade do mundo que apontam para sistemas de valores que caracterizam os grupos sociais. Ou seja, para que o acontecimento exista é necessário nomeá-lo. O acontecimento não significa em si. O acontecimento só significa enquanto acontecimento em um discurso (CHARAUDEAU, 2010, p. 131-132).

Outro fato que não podemos desconsiderar é que o jornalista não é um ser forado-mundo ao qual interpreta. Pelo contrário, o julgamento daquilo que é continuidade ou descontinuidade da ordem do mundo será feito a partir de suas crenças e valores pessoais e que ele julga compartilhados com o enunciatário a quem se dirige. Quando essa descontinuidade ocorre no campo religioso, a opinião se confunde com a crença e a percepção dessa ruptura é atravessada por estereótipos, passando a apoiar-se numa 
espécie de verdade constituída à qual o sujeito adere de maneira não racional. $\mathrm{O}$ discurso passa a ser composto por enunciados que se complementam como verdades universais que são, para o enunciador, um mundo de evidência capaz de tranquilizá-lo.

A crença [...] é, pois, um domínio que se define pelo encontro entre uma verdade como "saber que se sabe saber" e um sujeito que se dirige a essa verdade animado de uma "certeza sem provas" e que dela se apropria. Reconhecem-se aqui os movimentos individuais ou coletivos de adesão a grandes sistemas de pensamento ou a algumas narrativas do mundo que constituem o suporte das crenças religiosas, mágicas ou míticas [...]. Toda adesão a ideias preconcebidas, a rumores, a julgamentos estereotipados que aparecem sob a forma de enunciados mais ou menos fixos [...] que circulam nos grupos sociais, participa desse fenômeno de crença (CHARAUDEAU, 2010, p. 121).

Percebe-se esta condição com clareza quando analisamos o corpus desta pesquisa. Retomando o texto do jornal Crítica, podemos claramente ver no discurso imagético o mesmo processo de construção de sentidos do texto escrito, evidenciando a elaboração do acontecimento midiático atravessado pela percepção e pelas crenças de um sujeito enunciador, cristalizando-se no discurso que este faz sobre o acontecimento.

O texto traz na margem superior direita uma foto de uma senhora diante de uma árvore apanhando folhas. A imagem em si não representa nenhuma captura de um acontecimento que tenha rompido com a ordem do mundo cotidiano. A imagem por si só fixa o acontecimento na ordem do natural e do comum, porém, os títulos grandes que preenchem os espaços superior, lateral e inferior à foto, assim como a legenda que a acompanha, constroem o acontecimento e o inscrevem na ordem do sobrenatural, daquilo que rompe com a ordem do mundo, como se vê na figura abaixo: 
Figura 1 - Jornal Crítica, 07 de novembro de 1929

\section{Para as Suas "Mandingas e Trabalhos" a Bru. xa de Itinga Emprega Bichos e Pós Venenosos}

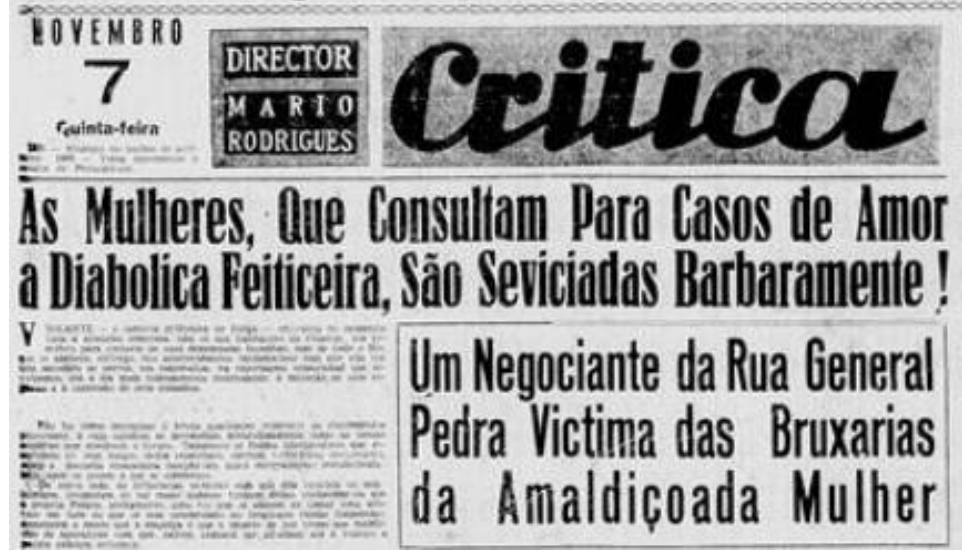

Fonte: Hemeroteca Digital da Biblioteca Digital/Jornal Crítica.

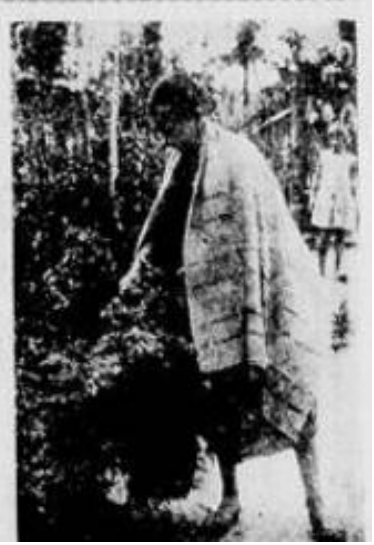

A legenda da foto diz o seguinte: "A bruxa apanha folhas para confecção de seus pós misteriosos e satânicos". A imagem que ancora o acontecimento na vida cotidiana e produz um efeito de verdade, como aquilo que "faz-crer" - a "captura do real", como apreensão do fato tal qual se deu na vida cotidiana -, tem o sentido deslocado pelo texto escrito para uma interpretação que transcende esse lugar comum registrado na imagem. Em outros termos, o texto imagético que de início é a prova da natureza comum do acontecimento, transforma-se na relação com o texto escrito, tornando-se evidência do rompimento da ordem do mundo.

Logo abaixo da foto e dos títulos e intertítulos que definem a perspectiva do enunciador com termos como "bruxa de Itinga", "diabólica feiticeira", "amaldiçoada mulher", existe um desenho ilustrativo que, na verdade, atua como uma caricatura. No entanto, não acentua atributos físicos do objeto caricaturado, mas as vicissitudes de natureza moral e de desvio, como se vê na imagem abaixo: 


\section{míDiA

Figura 2 - Ilustração de apoio ao texto, Jornal Crítica, 07 de Novembro de 1929

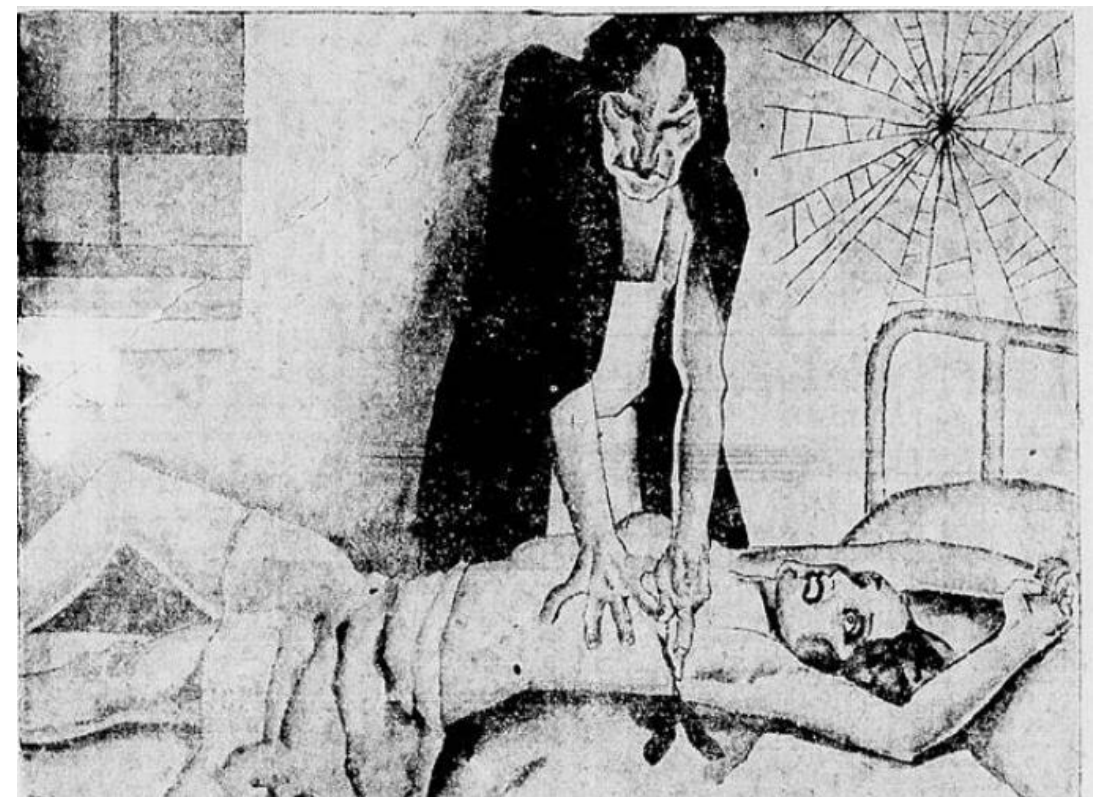

Fonte: Hemeroteca Digital da Biblioteca Digital/Jornal Crítica.

A legenda da imagem diz o seguinte: "E a bruxa, navalha em punho, abre nas carnes da vítima a incisão maravilhosa que a fará feliz no amor”. Observe que a escolha do termo "vítima" ao invés de simplesmente "a mulher", ou, "a crente" imputa à que pratica a ação um ato de maldade. A ação praticada é qualificada como má porque a agente passiva, que recebe a ação, é chamada de vítima.

A narrativa que acompanha a imagem ilustrativa diz o seguinte:

A bruxa de Itinga, em meio ao Sabat, grita esse nome [Violante] que é o seu, aos duendes maus e aos bodes pretos. E para eles estas quatro sílabas tem um poder sobrenatural. A enviada de Satan exulta de demoníaca alegria quando alguém a procura para fazer mal [...]. As mulheres são as melhores consulentes de violante. E para elas a megera emprega uma sorte de magia original e infalível. Ordena Violante que a paciente se dispa. Depois sobre o peito esquerdo, com uma navalha, faz uma incisão de alguns centímetros. O sangue jorra em borbotões. A feiticeira, então, com um morcego sinistro, suga a ferida longamente, sequiosamente, tragicamente (CRÍTICA, 1929).

A narrativa é interessante por ser uma construção discursiva feita a partir de relatos de outras testemunhas. No entanto, observa-se como o tempo verbal recoloca o enunciador na cena como se ele próprio tivesse testemunhado os fatos que narra, prática comum no estilo literário assumido pelo jornalismo na época. O discurso se constrói a 


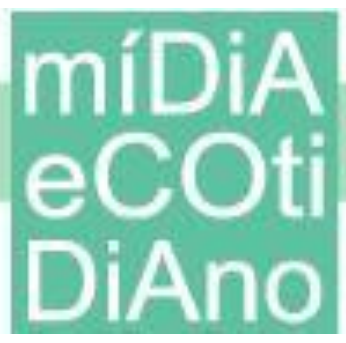

partir de um "saber que se sabe saber", pois, só desse modo é possível ao enunciador afirmar conclusivamente que as quatro sílabas do nome Violante têm para os duendes maus e os bodes pretos um poder sobrenatural. De que outro modo ele poderia provar a evidência dessa afirmação, senão apenas no próprio discurso que enuncia?

As imagens colocadas lado a lado exemplificam a distância entre o acontecimento e a percepção e significação que o sujeito enunciador atribui a ele. De um lado uma cena do cotidiano e do outro aquilo que o enunciador com a sua percepção atravessada pelas crenças e valores pessoais vê quando olha para a cena, corroborando a fala de Lippmann (2008, p. 83) quando afirma que "o que frequentemente se imagina ser o relato de um evento é, na realidade, a sua transfiguração".

Tabela 1 - A interpretação e construção do acontecimento

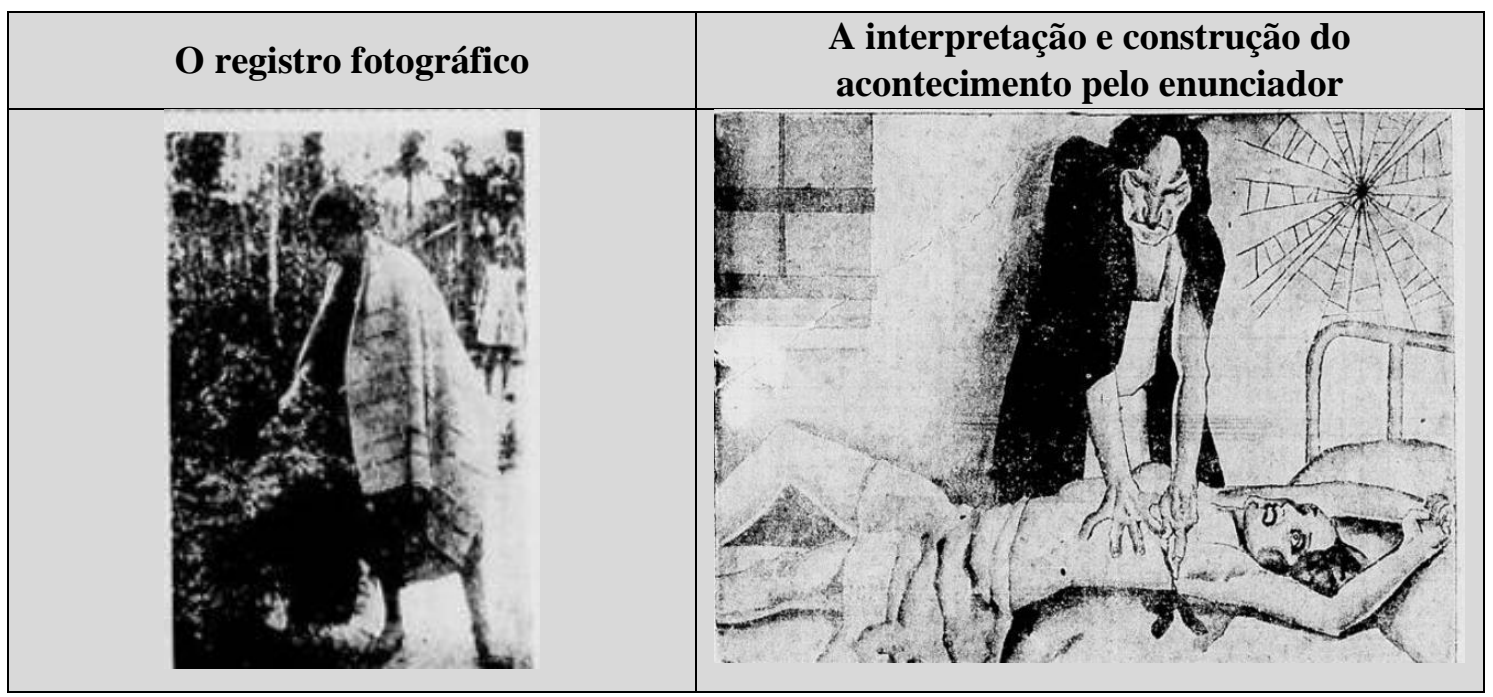

Fonte: Hemeroteca Digital da Biblioteca Digital/Jornal Crítica.

A partir do material apresentado, constata-se, de modo evidente, o uso e o funcionamento dos estereótipos no processo de produção de sentidos, assunto que trataremos mais profundamente no tópico seguinte.

\section{Os estereótipos no processo de construção do acontecimento}

Em 1922, Walter Lippmann publicou o livro Opinião Pública no qual dedicou um capítulo à questão do estereótipo. Para o jornalista, estereótipos são imagens mentais que medeiam nossa relação com o real. Nós vemos o mundo da maneira como fomos 
ensinados culturalmente a ver, pois, essas imagens mentais advindas das representações culturais preexistentes filtram a nossa percepção do real.

Há uma imagem mais ou menos ordenada e consistente, a qual nossos hábitos, nossos gostos, nossas capacidades, nossos confortos, nossas esperanças se ajustaram. Elas podem não ser uma imagem completa do mundo, mas são uma imagem de um mundo possível ao qual nós nos adaptamos. Naquele mundo as pessoas e as coisas têm seus lugares bem conhecidos, e fazem certas coisas previsíveis. Sentimo-nos em casa ali. Enquadramo-nos nele. Somos membros. Conhecemos o caminho em volta. Ali encontramos o charme do que é familiar, o normal, o seguro (LIPPMANN, 2008, p. 96).

Nesse caso, o estereótipo passa a ter um sentido positivo e um negativo no âmbito das ciências sociais e humanas. É positivo quando visto como "fator de coesão social, elemento construtivo na relação do ser humano consigo mesmo e com o outro"6 (AMOSSY; PIERROT, 2010, p. 47, tradução nossa). No entanto, quando se transforma em uma categorização simplificada e/ou generalizada pode oferecer uma visão deturpada do real, pois, "como os estereótipos comumente referem ao todo selecionando alguns detalhes, tendem a oferecer uma imagem incompleta (eventualmente, errada), que implica ou provém de uma qualificação ou julgamento" (CARMELINO; POSSENTI, 2015, p. 419).

Esta situação pode ser observada no segundo texto selecionado, publicado em 1924 no Jornal do Brasil, com autoria de Benjamim Costallat:

A porta de entrada, rapidamente, se havia fechado e não havia uma janela que desse um pouco de ar àquela aglomeração de gente, suando e fedida [...]. O negro, na sua linguagem africana, recomeçou a soltar a sua eloquência terrível e diabólica [...]. Na meia luz de querosene, aquelas criaturas, quase todas pretas, pareciam ter saído de uma gravura de madeira. Eram sinistras...[...]. O preto feiticeiro, o "pai de santo", soltando para o teto enormes fumaradas, agitava-se, tremendamente, com grandes gestos, grandes gritos, batendo no peito com terrível estrondo [...]. De repente, o feiticeiro começou a dar pulos, a rodopiar, num samba infernal. Parecia uma carrapeta viva [...]. A carrapeta humana não se cansava. Era vertiginosa e louca. E cada vez mais o seu imenso charuto soltava fumaça [...] como se sua cabeça negra estivesse a incendiar-se! [...]. E ereto, como uma estátua de bronze, o braço levantado, imponente de atitude [...], recomeçou a falar velozmente na

\footnotetext{
${ }^{6}$ Texto original: “[...] un factor de cohesión social, un elemento constructivo en la relación del ser humano consigo mismo y con el otro".
} 
sua linguagem africana [...]. O preto e seu enorme charutão - já devia ser outro porque ele era enorme - lançando fumaça como uma chaminé, dirigiu-se para a velha gorda e como querendo hipnotiza-la, abriu os braços fazendo uma série de "passes" diante de sua pobre cabeça dolorida [...]. E, rapidamente, dentro do barracão, tendo como centro o "pai de santo", rodopiam furiosamente quatro homens e quatro mulheres, fazendo um barulho de mil infernos com os seus pés nus, no soalho que vibra, estremecendo a casa [...]. É uma visão louca! [...]. E tudo roda, e tudo vira, e tudo samba, um samba doido e diabólico numa alucinação tremenda! (COSTALLAT, 1924).

O texto começa com a narrativa do medo e ansiedade do jornalista e sua fonte, escondidos em um matagal no subúrbio carioca, na expectativa de testemunharem um culto afro-brasileiro que aconteceria em um barracão. Nesse ponto, o texto abre espaço para uma descrição minuciosa da vida social no subúrbio em contraste com o que acontecia na região urbana do centro do Rio. O trecho citado acima é a narrativa das percepções do jornalista ao testemunhar a celebração de um culto umbandista, visto que a religião é nominalmente citada em um momento posterior ao que aqui destacamos.

Da leitura do texto, destaca-se a qualificação que o enunciador faz da manifestação religiosa que testemunha em expressões recorrentes ao longo de toda a narrativa como: diabólico, infernal, feiticeiro. A recorrência a esses estereótipos são uma forma de explicar aquilo que para o enunciador é incompreensível por transgredir os valores e crenças com os quais está habituado. Os estereótipos, nesse caso, são ao mesmo tempo a distinção e a homogeneização do acontecimento, pois, por um lado o diabólico foge da visão de natureza sacralizada do mundo e por outro iguala qualquer diferença dessa saliência "sobrenatural" situando o fato narrado em um lugar comum e partilhado socialmente, numa visão culturalmente aprendida daquilo que é diabólico.

Esta estereotipia, no entanto, não é produto deste período histórico: a construção do imaginário social sobre o inferno, o demônio e o diabo na América Latina remontam ao período colonial, pois, os colonizadores trouxeram da Europa uma visão de mundo fortemente influenciada pelo dualismo entre o bem e o mal, entre Deus e o diabo, influenciados pelas contendas religiosas da Reforma e da Contrarreforma, inserindo a religião em lugar de destaque no cotidiano (SOUZA, 1993, p. 22). 
Souza (1993) acredita que foi na caça às bruxas que o olhar demonológico sobre a América Latina foi treinado, o que fez com que entre uma bruxa basca e um índio idólatra existisse uma linha muito tênue para um espanhol do século XVI (SOUZA, 1993, p. 26).

Estabeleceu-se desse modo uma visão dicotômica que por um lado justificava o processo colonizador baseada no imaginário edênico ressaltando as propriedades e qualidades sacras da terra e, por outro, demonizava seus habitantes para justificar a violência no processo de conquista e apropriação da Terra. Corroborando esta perspectiva, Holanda (2010) indica a exaltação da natureza edênica do país ao analisar as narrativas dos descobridores da América do Sul e, mais especificamente, do Brasil, enumerando uma série de descrições presentes nas narrativas tais como: imunidade a doenças, plantas com poder curativo, frutas de sabores exóticos, animais falantes (papagaio), entre outras.

Nessa mesma perspectiva, Schwarcz (2012) entende que o imaginário do paraíso edênico aparecia com muito vigor nas narrativas dos primeiros descobridores estabelecendo uma clara distinção entre a terra e os naturais da terra:

O Brasil seria o paraíso ou o inferno? Seus habitantes, ingênuos ou viciados? Ou seja, a presença do motivo edênico e paradisíaco da terra começou com os primeiros europeus que dela se acercaram. Está presente já em Caminha, e logo depois em 1502 na carta de Américo Vespúcio, que ficou conhecida como mundus novo - na qual declarou que o paraíso terreal não estaria longe dessas terras -, e também em Gândavo, em sua História da Província de Santa Cruz de 1576, que descreveria o país a partir de sua fertilidade e de seu clima ameno e receptivo. Mas Gândavo também seria o autor de uma máxima que definiria de forma direta, não tanto a natureza do Brasil, mas seus naturais: povos sem F, sem L e sem R: sem fé, sem lei e sem rei (SCHWARCZ, 2012, p. 12).

Essa dicotomia é interpretada pela autora como uma relação constituída no imaginário cristão envolvendo o paraíso e o inferno, já que ao descrever os indígenas brasileiros "como 'atrevidos, sem crença na alma, vingativos, desonestos e dados à sensualidade', Gândavo estabelecia uma distinção fundamental entre a terra e seus homens: a edenização de um lado, o inferno do outro" (SCHWARCZ, 2012, p. 15).

Com a escravização que igualava socialmente indígenas e africanos e o esgotamento do apresamento de índios no século XVI, os escravizados trazidos da África 
passaram a ser identificados quase que exclusivamente com o lugar mais baixo no substrato social. Conforme apontava Bastide (1960), constituiu-se uma "nova estratificação onde o branco ocupava o ápice, o mestiço livre ou caboclo a intermediária e ele a camada mais baixa de todas, ou seja, a da escravidão" (BASTIDE, 1960, p. 64).

Inserida neste contexto, a Igreja Católica que, em linhas gerais, se manifestou contra escravidão do índio alegando que a prática era impeditiva de sua evangelização, acabou por permitir tanto a escravização indígena quanto a do africano por considerar, como apontou Anchieta (1992), que a pena da escravidão é seguramente menor do que a eternidade no inferno, visto que a retirada destes indivíduos da condição não civilizada e, portanto, sujeita às interferências do demônio é, em qualquer circunstância, um benefício para os gentios. Assim, os estereótipos associados pelos primeiros colonizadores aos índios sequenciados pelos africanos e à sua forma de religiosidade tornaram-se constitutivo das relações sociais e culturais no Brasil. Por mais que a Igreja Católica insistisse na responsabilidade dos senhores para evangelização dos escravizados, na prática mostra que isto era ignorado, pois, os africanos eram considerados pelos brancos como animais sem alma. As representações coletivas inscreviam o negro como "coisa" e não como pessoa (BASTIDE, 1960, p. 185).

Assim, permanecendo por séculos a narrativa associando a cultura africana como uma intrusão diabólica no paraíso, os sujeitos e sobretudo a religião africana veem mantido esse status, mesmo depois da abolição da escravatura. Com isso, percebe-se que o diabólico não é apenas um modo de ser da religião alheia, constituindo-se espacialmente na periferia, lugar do substrato da vida social.

O paraíso, na concepção narrativa dos jornais do século XIX e início do XX, tem cor e raça, mas sobretudo está vinculado ao extrato social ao qual está associado o indivíduo. Pina (2018), observando as narrativas relacionadas aos italianos que chegam a São Paulo para substituir a mão-de-obra escravizada constata, a partir da análise de matérias publicadas no jornal A Província de São Paulo (atual O Estado de S.Paulo) entre os anos de 1875 e 1899, que apesar de, em linhas gerais, o europeu ser tratado como cristão, trabalhador e civilizado, enquanto o negro é violento, indolente e descrente, ocorre um deslocamento semântico que em última instância insere o italiano no território antagônico, na medida em que é retratado como gerador de balbúrdia, briguento, 


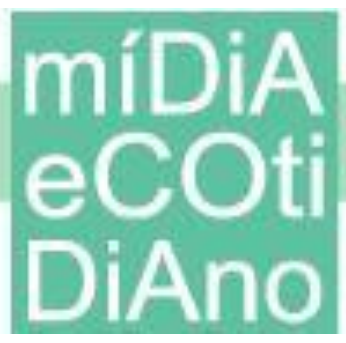

enganador ou vagabundo, atributos que também são associados aos escravizados. Mesmo sendo europeu, traços "não civilizados" são enaltecidos nas narrativas jornalísticas, constituindo estereotipias divergentes nos termos, mas similares no propósito.

Assim, nas relações sociais, o lugar possível para a africanidade era a marginalidade, espaço de atuação do diabólico: como apontava Bastide (1960), “o mulato livre e sobretudo a mulata voluptuosa bem podiam encontrar aqui um paraíso, o escravo negro apenas encontrando um inferno" (BASTIDE, 1960, p. 94).

No campo da normatização da vida social, a escravidão abolida em 1888 foi substituída por outros instrumentos de controle desta população: em 1890 o código penal ${ }^{7}$ passou a tipificar como crime a vadiagem, a mendicância, a beberagem e, também, a capoeira. Conforme aponta Santos (2004),

No final do século XIX, com a abolição da escravatura, negros libertos, em grande número, deslocavam-se para as cidades à procura de oportunidades e quando lá chegavam não conseguiam ser absorvidos em atividades remuneradas. $\mathrm{O}$ crescimento do número de imigrantes, vindos tanto do interior do Brasil, quanto do exterior também contribui para o crescimento urbano desordenado. Capoeiras, que eram utilizados tanto por liberais, como por conservadores como uma milícia paramilitar, ficaram na República fora do controle das autoridades. Capoeiras, negros alforriados, imigrantes e pobres eram apontados pelos chefes de polícia como sendo os principais responsáveis pelo número cada vez maior de roubo, latrocínio e prostituição (SANTOS, 2004, p. 145).

Finalizando a construção do cenário cultural do qual emergem as narrativas contidas nos jornais cariocas da década de 1920, é preciso delinear mais um elemento importante: a eugenia. Schwarcz (1996) observou que no final do século XIX a eugenia e o combate a miscigenação racial ganharam destaque no Brasil respaldados pelo discurso científico, mais especificamente, da medicina. Boa parte das mazelas da sociedade brasileira, tais como doenças, enfraquecimento biológico, criminalidade e atraso cultural eram apontados como resultado de uma herança africana trazida para o Brasil durante o período colonial:

\footnotetext{
${ }^{7}$ Decreto $\mathrm{n}^{\circ} 847$, de 11 de outubro de 1890. Disponível em: http://www.planalto.gov.br/ccivil_03/decreto/1851-1899/d847.htm. Acesso em: 06 mar. 2021.
} 
Na Bahia, em finais do século [XIX], as teses sobre medicina legal predominam. Nelas, o objeto privilegiado não é mais a doença ou o crime, mas o criminoso. Sob a liderança de Nina Rodrigues, a faculdade baiana passou a seguir de perto os ensinamentos da escola de criminologia italiana, que destacava os estigmas próprios dos criminosos: era preciso reservar o olhar mais para o sujeito do que para o crime. Para esses cientistas, não foi difícil vincular os traços lombrosianos ao perfil dos mestiços - tão maltratados pelas teorias da época - e aí encontrar um modelo para explicar a nossa "degeneração racial". Os exemplos de embriaguez, alienação, epilepsia, violência ou amoralidade passavam a comprovar os modelos darwinistas sociais em sua condenação do cruzamento, em sua alerta a "imperfeição da hereditariedade mista" (SCHWARCZ, 1996, p. 92).

Voltando ao texto de Costallat, podemos notar como esses estereótipos se cristalizam no discurso opinativo do autor. Primeiramente percebemos um constante processo de animalização e objetificação do negro em expressões como: "aquelas criaturas, quase todas pretas", "gente suada e fedida", "saída de uma gravura em madeira", "carrapeta viva", "lançando fumaça como uma chaminé", "estátua de bronze". É evidente como o discurso harmoniza em um mesmo dizer o diabólico e infernal com o animalesco e objetificado (sem alma) qualificando, dessa forma, com a estereotipia, a religião e seu adepto.

Por fim, salientamos, ainda, a maneira como o enunciador caracteriza a prática religiosa como um estado de loucura empregando descrições como: "agitava-se, tremendamente, com grandes gestos, grandes gritos, batendo no peito com terrível estrondo"; também em: "era vertiginosa e louca"; e ainda em: "rodopiam furiosamente quatro homens e quatro mulheres, fazendo um barulho de mil infernos com os seus pés nus, no soalho que vibra, estremecendo a casa [...]. É uma visão louca!”.

As percepções do enunciador sobre o acontecimento que narra cristaliza no discurso as práticas sociais herdadas de um processo de colonização que, apesar de ter tido seu fim declarado, construiu lugares sociais sólidos, porém, estereotipados, que persistiram no imaginário social delimitando muito claramente o lugar da religiosidade afro-brasileira. 


\section{míiA

\section{Considerações finais}

Ao longo deste texto, pudemos perceber como os estereótipos orientam a percepção das práticas jornalísticas na construção do acontecimento, especialmente, dentro do recorte temporal e das narrativas selecionadas para composição do corpus desta pesquisa tendo como objeto o discurso sobre a religiosidade afro-brasileira.

Talvez a estilística mais literária do jornalismo brasileiro na década de 1920 permitisse a exacerbação dos adjetivos e até a imbricação, em alguns casos, de fato e ficção em uma mesma narrativa sobre o acontecimento. Mas, fica evidente pelo corpus analisado, como a estereotipia do negro constituída desde o período colonial, consolidada pelo aparato legal e o discurso médico no final do século XIX e no início das primeiras décadas do século seguinte, se cristaliza com clareza no discurso que a imprensa carioca faz sobre a religiosidade afro-brasileira, mais especificamente à Umbanda.

Percebemos que o diabólico e o louco, estereótipos que se manifestam com força nos discursos analisados, possui uma raça (o negro), um estrato social (o pobre), e um lugar (a periferia). O lugar de fala dos sujeitos enunciadores, que no caso dos textos analisados são os jornalistas, estabelece um contraponto, um lugar social correlato do branco, rico e do centro que corresponde a uma visão de mundo compartilhada com o enunciatário, a quem o periódico se dirige. É desse modo que os preconceitos raciais e sociais - cuja origem é histórica - se cristalizam nos discursos sobre a religiosidade afrobrasileira por meio da estereotipia na imprensa carioca na década de 1920 .

Depois da adoção das técnicas americanas pelo jornalismo brasileiro para a construção da notícia a partir da década de 1940, a narrativa dos periódicos procura criar um efeito de isenção, esvaziando o texto das expressões emocionais do jornalista, bem como de suas adjetivações e opiniões. Há indicativos no corpus da pesquisa, que abrange produções das décadas subsequentes e que serão demonstrados em outros artigos, de que esta alteração do padrão narrativo não retira do periódico o traço de estereotipia, uma vez que mesmo sendo isento de adjetivações o texto verbal, esta característica permanece nas imagens publicadas, possibilitando a manutenção da cadeia de transmissão intergeracional.

Com o advento das novas tecnologias da informação e com a possibilidade do leitor de comentar a notícia e expressar a sua opinião, observamos que a mesma 
estereotipia permanece ativa no seio social e cultural manifestando, desse modo, os mesmos estereótipos sobre a religiosidade afro-brasileira, conforme indicado brevemente na epígrafe que abre esse artigo.

Entendemos que a proposta deste trabalho não é a de generalizar suas constatações, porém, compreendemos que os caminhos percorridos ao longo do artigo podem apontar uma possibilidade plausível para investigar os discursos de intolerância religiosa que emergem na contemporaneidade retomando a sua origem sócio-histórica e o processo de apropriação e reverberação desses estereótipos na mídia consolidando-os no imaginário social.

\section{Referências}

AMOSSY, R.; PIERROT, A. H. Estereotipos y Clichés. Buenos Aires: Eudeba, 2010.

ANCHIETA, J. Carta ao Geral Diogo Laines, de São Vicente, 8 de janeiro de 1565. In: RIBEIRO, D.; MOREIRA NETO, C. D. A (orgs.). A fundação do Brasil. Testemunhos 15001700. Petrópolis: Vozes, 1992.

BARTHES, R. Elementos de Semiologia. São Paulo: Cultrix, 2006.

BASTIDE, R. As religiões africanas no Brasil. São Paulo: Livraria Pioneira Editora; EDUSP, 1960.

BRANDÃO, H. H. N. Introdução à análise do discurso. Campinas: Editora Unicamp, 2004.

CARMELINO, A. C.; POSSENTI, S. O que dizem do Brasil as piadas? Linguagem em (Dis)curso - LemD, Tubarão, SC, 15, n. 3, set. / dez. 2015. 415-430. Disponivel em: https://www.scielo.br/pdf/ld/v15n3/1518-7632-ld-15-03-00415.pdf. Acesso em: 9 out. 2020.

CHARAUDEAU, P. Discurso das mídias. São Paulo: Contexto, 2010.

DEL PRIORE, M. Do outro lado. A história do sobrenatural e do espiritismo. São Paulo: Planeta, 2014.

GIL, A. C. Como elaborar projetos de pesquisa. São Paulo: Atlas, 2002.

GILL, R. Análise de discurso. Petrópolis: Vozes, 2002.

HOLANDA, S. B. D. Visão do Paraíso: os motivos edênicos no descobrimento e colonização do Brasil. São Paulo: Companhia das Letras, 2010.

JARDIM, J. L. Imprensa operária: comunicação e organização. Estudos Iberoamericanos, Porto Alegre, 22, n. 2, dez 1996. 27-40. Disponivel em: https://revistaseletronicas.pucrs.br/ojs/index.php/iberoamericana/article/download/28550/15960/ 0. Acesso em: 25 mar. 2021.

LIPPMANN, W. Opinião Pública. Petrópolis: Vozes, 2008. 
MAINGUENEAU, D. Novas tendências em Análise do Discurso. Campinas: Pontes; Editora Unicamp, 1997.

ORLANDI, E. P. Discurso e texto: formulação e circulação dos sentidos. Campinas: Pontes, 2011.

PÊCHEUX, M. Análise automática do discurso (AAD-69). In: GADET, F; Hak, T (orgs). Por uma análise automática do discurso: uma introdução à obra de Michel Pêcheux. Campinas: Editora Unicamp, 1997.

PEREC, G. Lo infraordinario. Madri, Espanha: Impedimenta, 2008.

PINA, J. A. Tutti Buona Gente? O imaginário midiático do imigrante italiano no jornal "O Estado de S.Paulo" no final do século XIX. 2018. Dissertação (Mestrado em Comunicação) Programa de Pós-graduação em Comunicação, Universidade Paulista, São Paulo. Disponivel em: http://repositorio.unip.br/programa-de-pos-graduacao-stricto-sensu-em-comunicacao/tuttibuona-gente-o-imaginario-midiatico-do-imigrante-italiano-no-jornal-o-estado-de-s-paulo-nofinal-do-seculo-xix/. Acesso em: 20 fev. 2019.

PISA, L. F.; SOUZA, R. M.; VISIBELI, D. Análise do discurso: conceitos e aplicações. Pouso Alegre: IFSULDEMINAS; Lume Editora, 2018.

RIBEIRO, A. P. G. Jornalismo, literatura e política: a modernização da imprensa carioca nos anos 1950. Estudos Históricos, Rio de Janeiro, 1, n. 31, 1 ago 2003. 147-160. Disponivel em: http://bibliotecadigital.fgv.br/ojs/index.php/reh/article/view/2186/1325. Acesso em: 23 jul. 2018.

RIO, J. D. As religiões no Rio. Rio de Janeiro: José Olympio, 2015.

SANTOS, M. S. D. A prisão dos ébrios, capoeiras e vagabundos no início da Era Republicana. Topoi, Rio de Janeiro, 5, n. 8, jun. 2004. Disponivel em: http://www.scielo.br/scielo.php?script=sci_arttext\&pid=S2237101X2004000100138\&lng=en\&nrm=iso. Acesso em: 15 mar. 2021.

SCHWARCZ, L. M. Usos e abusos da mestiçagem e da raça no brasil: uma história das teorias raciais em finais do século XIX. Afro-Ásia, Salvador, n. 18, 1996. 77-101. Disponivel em: https://periodicos.ufba.br/index.php/afroasia/article/view/20901/13519. Acesso em: 20 ago. 2019.

SCHWARCZ, L. M. Nem preto nem branco, muito pelo contrário: cor e raça na sociabilidade brasileira. São Paulo: ClaroEnigma, 2012.

SILVA, M. R. Umbanda e os meios de comunicação: documentos para a compreensão da história e atualidade desta religião brasileira. In: CAMARGO, H. W. (org.) Umbanda, cultura e comunicação: olhares e encruzilhadas. Curitiba: Syntagma Editores, 2019.

SOUZA, L. D. M. E. Inferno atlântico: demonologia e colonização - séculos XVI - XVIII. São Paulo: Companhia das Letras, 1993. 


\section{Referências do corpus}

COSTALLAT, Benjamim. Na noite do subúrbio. Jornal do Brasil, Rio de Janeiro 24 de Maio, 1924. Hemeroteca Digital da Biblioteca Nacional. Disponível em:

http://memoria.bn.br/DocReader/DocReader.aspx ?bib=030015_04\&PagFis=29481\&Pesq=umb anda. Acesso em: 10 abr. 2020.

CRÍTICA. Para as suas "mandingas e trabalhos" a bruxa de Itinga emprega bichos e pós venenosos. Rio de Janeiro, 07 de Nov. 1929. Hemeroteca Digital da Biblioteca Nacional.

Disponível em: http://memoria.bn.br/docreader/DocReader.aspx?bib=372382\&PagFis=2275. Acesso em: 13 abr. 2020.

PORTAL G1. Baianos e turistas celebram Iemanjá em Salvador; multidão se forma no Rio Vermelho. Bahia, 02/02/2020. Disponível em:

https://g1.globo.com/ba/bahia/verao/2020/noticia/2020/02/02/baianos-e-turistas-reverenciamiemanja-e-multidao-se-forma-no-rio-vermelho-em-salvador.ghtml. Acesso em: 25 abr. 2020. 